\title{
Effect of hypodynamia on structure of vestibular apparatus in Japanese quail chicks: light microscopy
}

\author{
Lenka Buričová ${ }^{1}$, Peter Škrobánek², Magda Baranovská ${ }^{2}$ \\ ${ }^{1}$ Department of Anatomy, Histology and Physiology, University of Veterinary Medicine, Košice, \\ Slovak Republic \\ ${ }^{2}$ Institute of Animal Biochemistry and Genetics, Slovak Academy of Sciences, Ivanka pri Dunaji, \\ Slovak Republic
}

Received February 2, 2010

Accepted September 21, 2010

\begin{abstract}
The model for studying the effects of simulated microgravity on the bird organism is hypodynamia. The aim of this study was to investigate the influence of chronic hypodynamia on the structure of the vestibular apparatus in Japanese quail by light microscopy. Morphological changes in the sensory epithelium of chicks reared under hypodynamia from 1 to 42 days of age were evaluated. The differences of shape and arrangement of hair cells in sensory epithelium macula utriculi and the dilatations on their basal parts were found in birds exposed to hypodynamia on day 14 and 42 compared to control.

The results confirmed that hypodynamia has specific impact on developmental processes in Japanese quail and indicated that similar damage of inner ear sensory epithelium could be developed in chicks hatched and reared in conditions of real weightlessness during the space flight.
\end{abstract}

Simulated weightlessness, inner ear, sensory epithelium

Vestibular apparatus is the sensory system which contributes to balance and spatial orientation of animals. It detects head movements and gravitational stimuli which are transferred upon the mechanosensory hair cells of the inner ear. The hair cells transduce these stimuli into electrical signals which are transmitted to brain (Colclasure and Holt 2003). The development and structural organization of the vestibular receptors under earthly conditions was described (Money et al. 1974; Fermin et al. 1998). However, fewer data are available from the studies of the influences of real microgravity on structure of vestibular apparatus in birds (Lychakov et al. 1993; Kenyon et al. 1995; Fermin et al. 1996), and therefore further information may be provided by the ground-based model of simulated weightlessness (hypodynamia). The first experiment to examine the effects of hypodynamia on the organism of Japanese quail was carried out on adult birds (Juráni et al. 1983). The aim of this experiment was to study the effect of simulated weightlessness on the development of structure of the vestibular apparatus in Japanese quail chicks reared under hypodynamia from 1 to 42 days of age.

\section{Materials and Methods}

Ten healthy 1-day-old male Japanese quail chicks (Laying Line 01 Ivanka pri Dunaji) were randomly divided into experimental group $(\mathrm{n}=5)$ and control $(\mathrm{n}=5)$. The birds of experimental group were exposed to hypodynamia and those of control were placed on the floor in rearing box as described by Škrobánek et al. (2004). The care and use animals were in accordance with laws and regulations of the Slovak Republic and were approved by the Ethics Committee of the Institute of Animal Biochemistry and Genetics, SASci, Ivanka pri Dunaji.

At days 1, 5, 14 and 42 of age, one bird of each group was decapitated and sample of tissues of inner ear was taken for histological analysis of vestibular apparatus. Excisions were fixed by immersion in 3\% glutaraldehyde in cacodylate buffer ( $\mathrm{pH} 7.2$ ), decalcified in Chelatone, post-fixed in $1 \% \mathrm{OsO}_{4}$, dehydrated in acetone and propyloxide and embedded into Durcupan ACM. For light microscopy, the semi-thin sections contrasted with toulidine blue were used.

Address for correspondence:

MVDr. Lenka Buričová-Tomková, PhD.

Department of Anatomy, Histology and Physiology

University of Veterinary Medicine, Košice

Phone: +421903185108

Komenskeho 73, 04181 Kosice, Slovak Republic 


\section{Results and Discussion}

No changes in the structure of the inner ear sensory epithelium of Japanese quail chicks reared under hypodynamia were observed at day 1 and 5 of age. There were local changes in structure of sensory epithelium in exposed quails compared to control at day 14 of age (Plate XIII, Fig.1). Changes of the shape and arrangement of hair cells were visible in macula utriculi. Dilatations were evident in the basal part of hair cells. The structure of hair cells was damaged and the shape of cells was changed. Apical and basal part of sensory epithelium in macula utriculi was partly violated.

At day 42 of age, there were more extensive structural changes of hair cells in macula utriculi of exposed quails (Plate XIV, Fig. 2) than those in the control birds at day 14. Basal membrane was damaged in a larger part of sensory epithelium and the arrangement of sensory cells in epithelium was irregular. Structure of hair cells was violated and their shape was changed as a result of extensive dilatation. Similar changes and arising dilatations were also observed around hair cells.

Our data confirmed that simulated weightlessness changed not only the shape and arrangement of hair cells in sensory epithelium macula utriculi but also induced the dilatations on basal part of hair cells at day 14 and 42 of age.

Similarly, other studies showed that the structure of the inner ear may be affected by conditions of real weightlessness. The mean number of synaptic ribbons in type II hair cells of rat utricular macula increased significantly in weightlessness whereas ribbon synapses of saccular type I hair cells displayed a significant decline early in flight and post flight and the saccular macula had less ultrastructural complexity than the utricular (Ross and Varelas 2005). In another study describing the development of vestibular efferent innervation in the utricular maculae from day 0 to 25 in rats kept in weightlessness, the main difference between postnatal day 8 and subsequent more mature stages was lower density of fibres and synapses in the utricle. However, maturation of the efferent system between day 8 and 23 was not sensitive to a change in the gravitational environment (Dememes et al. 2001).

Similarly, the differences in the vestibular system of 9 day old chicken embryos developed in weightlessness aboard the shuttle and those from ground-control were recorded (Fermin et al. 1996). By contrast, no substantial disturbance or delay in the formation of the vestibular apparatus was observed in Japanese quail embryos developed in weightlessness aboard the Mir space station from 1 to 12 days of age, although there was one distinct difference in the structural organization of the maculae and cristae between the quail developing in weightlessness as compared to control group (Lychakov et al. 1993).

The reason for these differences is not known but authors of these findings assumed that their possible causation could be an altered ionic metabolism of the inner ear fluids in weightlessness (Lychakov et al. 1993). Based on our results, we suppose that dilatations of hair cells were caused by an increased number of ribbon synapses rather than a consequence of partly changed intensity of gravity in conditions of hypodynamia. Ross (1998) assumed that a significant increase of the synapses of the hair cells of rat vestibular maculae in microgravity can be induced by stress. Unfortunately, the nature of these differences is still unknown.

In conclusion, this is the first study examining the effects of simulated weightlessness on the structure sensory epithelium of vestibular apparatus during postnatal development of Japanese quail males. These findings confirmed that hypodynamia has a specific impact on developmental processes in Japanese quail and that these data may be therefore useful for understanding quail development in conditions of real weightlessness.

\section{Vplyv hypodynamie na štruktúru vestibulárneho aparátu kurčiat prepelice japonskej: Svetelná mikroskopia}

Hypodynamia je model používaný pre skúmanie účinkov simulovanej mikrogravitácie na vtáčí organizmus. Ciel’om nášho výskumu bolo skúmat' vplyv chronickej hypodyna- 
mie na štruktúru vestibulárneho aparátu prepelice japonskej prostredníctvom svetelnej mikroskopie. U kurčiat odchovávaných v hypodynamii od 1 do 42 dní veku boli hodnotené morfologické zmeny zmyslového epitelu. Vo veku 14 a 42 dní boli zaznamenané početné rozdiely $\mathrm{v}$ tvare a usporiadaní vláskovitých buniek zmyslového epitelu macula utriculi a v ich bazálnych častiach zistené dilatácie v porovnaní s kontrolou.

Dosiahnuté výsledky potvrdili, že hypodynamia ma špecifický vplyv na vývinové procesy u prepelice japonskej a podobné poškodenie zmyslového epitelu vnútorného ucha by sa mohlo vyvinút' aj u kurčiat vyliahnutých a odchovávaných v podmienkach reálneho beztiažového stavu v priebehu kozmického letu.

\section{Acknowledgement}

This work was supported by the Grant Agency for Science of the Slovak Republic, VEGA grant No. 2/0047/09.

\section{References}

Colclasure JC, Holt JR 2003: Transduction and adaptation in sensory hair cells of the mammalian vestibular system. Gravitational and Space Biology Bulletin 16: 61-70

Dememes D, Dechesne CJ, Venteo S, Gaven F, Raymond J 2001: Development of the rat efferent vestibular system on the ground and in microgravity. Develop Brain Res 128: 35-44

Fermin CD, Lychakov D, Campos A, Hara H, Sondag E, Jones T, Taylor M, Meza-Ruiz G, Martid DS 1998: Otoconia biogenesis, phylogeny, composition and functional attributes. Histol Histopathol 13: 1103-1154

Fermin CD, Martin D, Jones T, Vellinger J, Deuser M, Hester P, Hullinger R 1996: Microgravity in the STS-29 space shuttle discovery affected the vestibular system of chick embryos. Histol Histopathol 11: 407-426

Juráni M, Výboh P, Lamošová D, Barošková Z, Somogyová E, Bod’a K, Gažo M 1983: The effect of a 90day hypodynamy on the neurohumoral system, egg laying and metabolism of proteins in Japanese quail. Physiologist 26: S145-S148

Kenyon RV, Kerschmann R, Sgarioto R, Jun S, Vellinger J 1995: Normal vestibular function in chicks after partial exposure to microgravity during development. J Vestib Res 5: 289-298

Lychakov DV, Iliinskaya EV, Dadasheva OA, Guryeva TS 1993: Swelling of calyx-like nerve endings in maculae and cristae of quail embryos exposed to weightlessness. Acta Vet Brno 62: 31-34

Money KE, Landolt JP, Correia MJ, Laufer J 1974: Anatomical and physiological investigations of vestibular system of birds. Brain Behav Evol 10: 212-227

Ross, MD 1998: Synaptic changes in rat maculae in space and medical imaging: the link. Otolaryngol Head Neck Surg 118: S25-S28

Ross MD, Varelas J 2005: Synaptic ribbon plasticity, ribbon size and potential regulatory mechanisms in utricular and saccular maculae. J Vestib Res 15: 17-30

Škrobánek P, Hrbatá M, Baranovská M Juráni M 2004: Growth of Japanese quail chicks in simulated weightlessness. Acta Vet Brno 73: 157-164 
Plate XIII

Buričová L. et al.: Effect of hypodynamia ... pp. 125-127
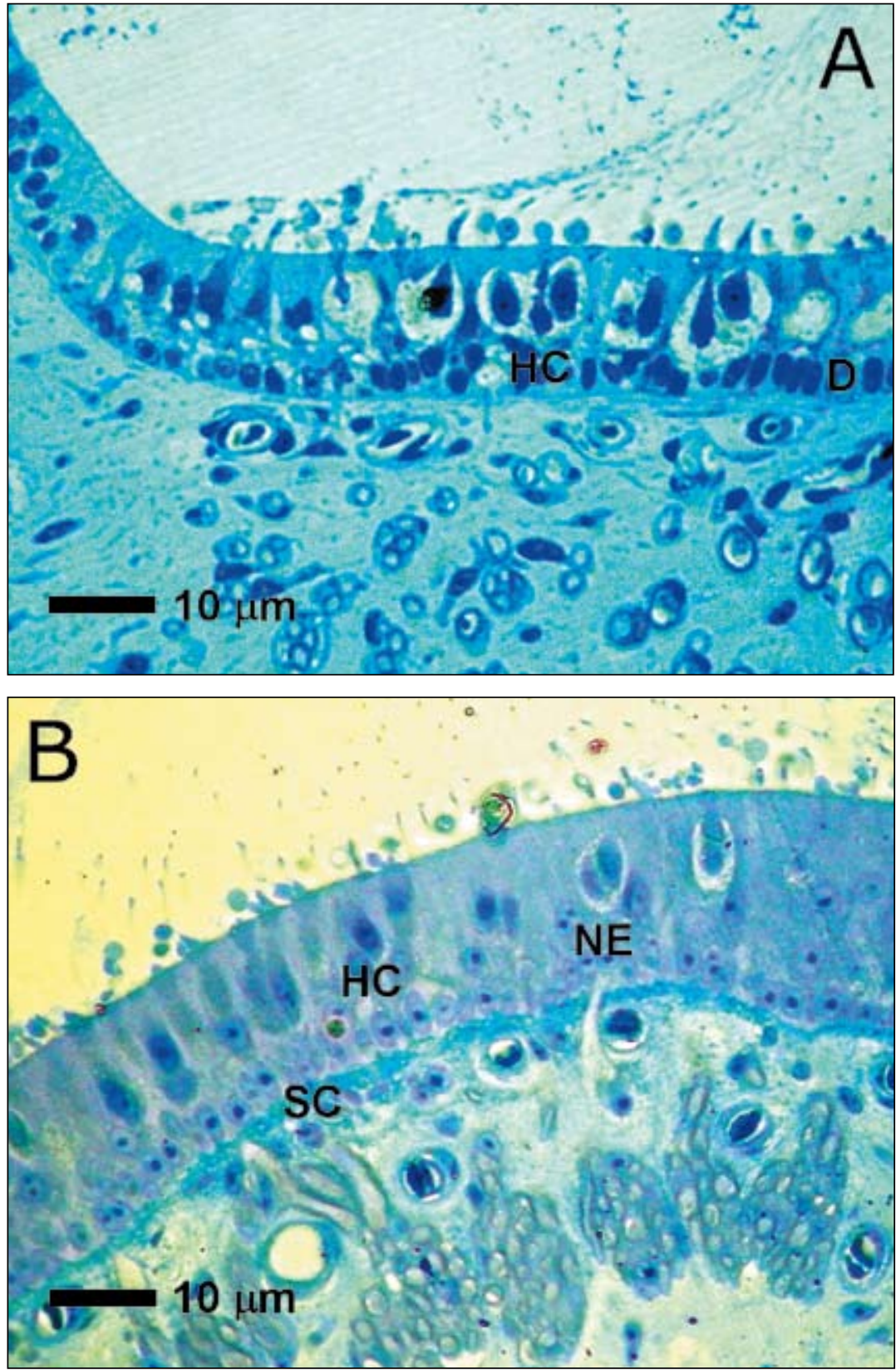

Fig. 1. Light microscopy of sensory epithelium (macula utriculi) of Japanese quail chick exposed to hypodynamia (A) and control (B) on day 14 of age $(\mathrm{M} \times 1000)$. (HC) hair cells, (D) dilatation, $(\mathrm{NE})$ nerve ending, (SC) supporting cell 

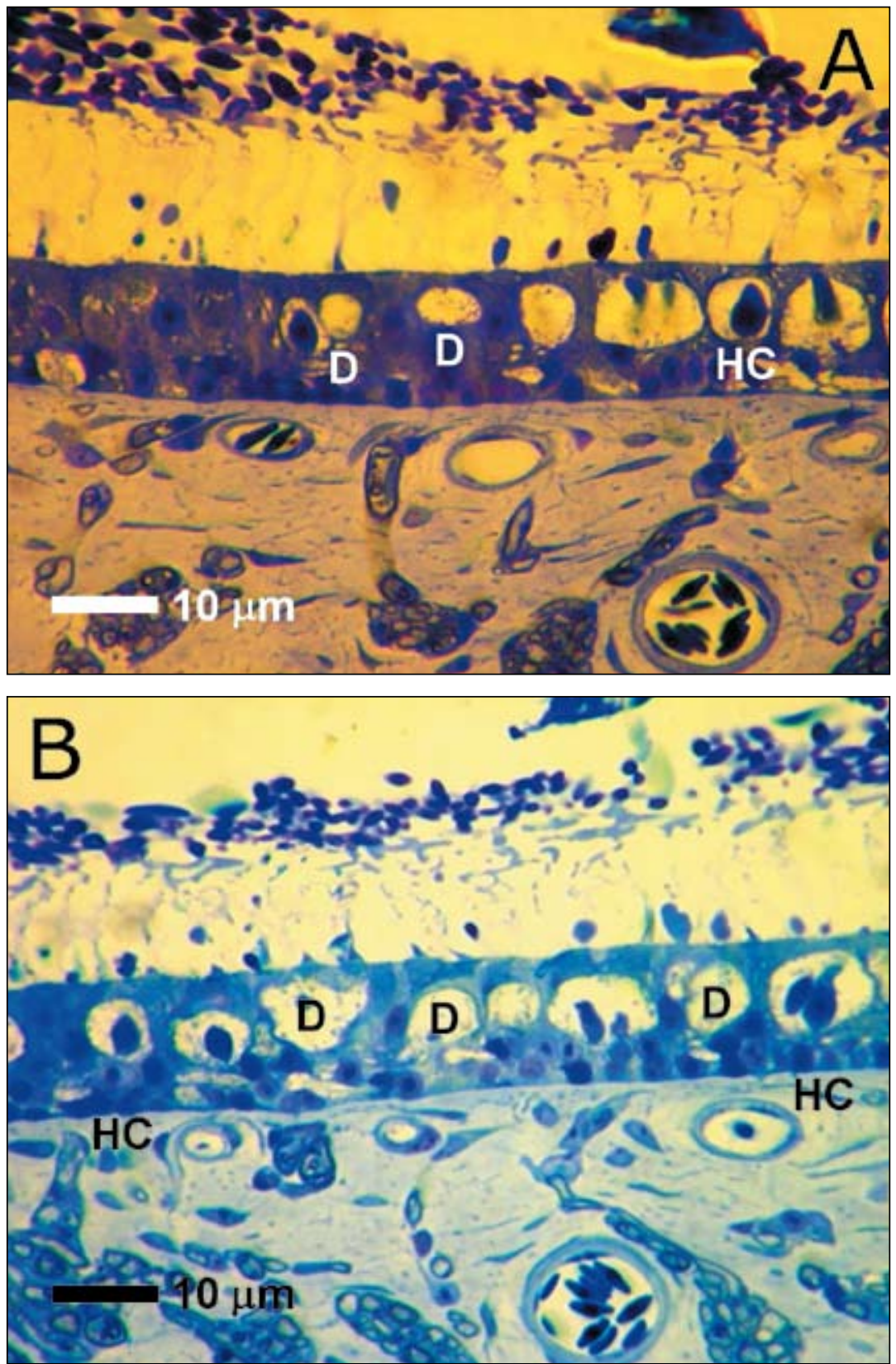

Fig. 2. Light microscopy of sensory epithelium (macula utriculi) of Japanese quail chick exposed to hypodynamia (A) and control (B) on day 42 of age $(\mathrm{M} \times 1000)$. (HC) hair cell, (D) dilatation 